\title{
NFC Technology on Integrated e-KTP for Health Service Post in Indonesia Based on Android
}

\author{
Ilham Al Fajri, Shinta Oktaviana R \\ Department of Informatics and Computer Engineering \\ State Polytechnic of Jakarta \\ Depok, Indonesia \\ ilhamalfajri24@gmail.com, shinta.oktaviana@tik.pnj.ac.id
}

Accepted: 12 September 2019. Approved: 28 Oktober 2019. Published: November 2019

\begin{abstract}
Integrated Service Post is a form of Community Based Effort implemented by, from and with the community, to empower and provide benefits for the community to provide health services for mothers, infants and toddlers. In the implementation of posyandu activities is still manual often posyandu officers about difficulties in terms of data recording and reporting data such as data posyandu patients are missing, unreadable, not written and not running properly. In this research, the application of integrated posyandu application with technology of field-based (NFC) android-based communication. Utilization of NFC technology allows to e-KTP with the data collection process can be done quickly and precisely. Posyandu application based on this android will also facilitate the officers in doing data recording just by using android smartphone. Posyandu officers which in addition this application can also be part of the smart city support application Depok.
\end{abstract}

Keywords: integrated service post; $n f c$; $e$ - ktp; android; smart city

\section{INTRODUCTION}

Primary health care in local area of Depok as a source of data from the health department of Depok City Government is still constrained in getting a recording of valid data reports from community health care activities. All task in community health care are still manually. Such as data recording and reporting process. Manual data recording and reporting has problems such as missing patient data, unreadable, not written and not stored well so reporting to the health and village offices is incomplete but it also makes policy decisions by posyandu, health and government to be not optimal. The need for a system for community health care volunteer in recording up to reporting is necessary to facilitate their work and make reporting can be done quickly and accurately to the health office and village as well as other parties (Interview with dr. Titin the Depok City Health Department, 2018).

e-KTP or Elektronik Kartu Tanda Penduduk is a residence document containing security system or control both from administration side or information technology based on national demographic database [8]. The residents are only allowed to have 1 (one) ID card which is registered with the Population Identity Number (NIK - Nomor Induk Kependudukan). NIK is the sole identity of every resident and is valid for life. E-KTP card has a chip that can be read by NFC Reader to identify user data accurately and accurately. In addition to integrating the system with e-KTP, the government will be able to monitor and determine effective policies on child health development in the jurisdiction of the government.

Therefore, to facilitate the volunteer in performing fast and precise data recording and reporting to health offices and sub-districts as well as assisting the government in determining effective and efficient policies, the design of integrated e-KTP integrated posyandu application with the utilization of near field technology communication (NFC) based on android. This application is expected to facilitate the cadres in the process of data recording and reporting, as well as with the NFC feature will also facilitate the registration process and data collection of patients who will all the data will be integrated with e-KTP is also expected to be part of the application support 
smart city in Depok. So that with this system can be a solution to help the existing problems in posyandu and government especially related to data recording, and also have an impact on society in the form of good and proper service improvement.

\section{ANDROID}

Android is an operating system for linux-based mobile devices that includes operating systems, middleware and applications. Android provides an open platform for developers to create new applications due to an open source-based operating system [7]. Initially, Google Inc. buy Android Inc. which is a newcomer who makes software for mobile phone or smart-phone. Then to develop Android, formed the Open Handset Alliance. Based on the Explanation, Android is a new generation of mobile platform that provides many free and open source development facilities so that currently widely used by programmers to develop applications to the mobile realm. Android apps can be easily developed using Android's IDE Studio from Google because it has many plugins that support for application development. Generally Android Studio uses Javabased programming language for its development.

In 2018, research by Nadia Savitri and Heru Nurwasito Informatics Engineering Study Program, Faculty of Computer Science, Brawijaya University entitled "Mobile Application Development for Posyandu Administration Service using Google Maps Fire Geo-location Tagging". In this research android application is made for posyandu administration service by utilizing Google Maps API feature which determine location and information of posyandu activity and this application also can be used for registration and recording data of posyandu patient.

\section{NEAR FIELD COMMUNICATION (NFC)}

Near Field Communication (NFC) technology is a short-range wireless technology designed to exchange quickly, exchange relevant information to make life easier and convenient for users in transactions such as accessing digital content, only to connect electronic devices with technology NFC with touch [5]. This requires a distance of about four centimeters to exchange information between two devices. NFC technology uses RFID (Radio Frequency Identification) to exchange data / information between two devices over short distances such as Bluetooth and Wi-Fi technology. NFC allows smart-phone users to transact and access information simply. NFC devices can send and receive data simultaneously. So this technology has a very bright future. As this is a new technology, mobile users need to provide information about NFC, about how NFC works to make payments or exchange information about e-KTP.

e-KTP is a national identity card based on National Identification Number that is made electronically and computerized and has specifications and National ID card format protected by a special security system as the official identity of the population issued by the Department of Population and Registry Civil [8]. Some of the benefits of using e-KTP, among them can create a complete and accurate database of population, so as to prevent the presence of people who have more than one or multiple ID cards and can be used as a sound card in the election, elections, and others. And able to identify or solve a difficult crime case such as terrorism crime, burglary bank via ATM, and other criminal acts [8].

Nurbek Saparkhojayev and the team of the Department of Electronics and Telecommunications POLITO, Torino, Italy under the title "Access Control and Management System Based on NFCTechnology by the Use of Smart Phones as Keys." In this study NFC technology is used to replace metal keys, cards and so on. From research conducted with NFC technology allows people to use only one single key to emulate smart cards and other keys [9].

Fagui Liu and the School of Computer Science and Engineering, South China University of Technology, Guangzhou, China, Italy under the title "The Application of NFC Verification System in Warehouse Management System" was established. In this study NFC technology is used to verify goods in warehousing management. From research conducted with NFC technology combined with the use of smart phones as carriers for the logistics industry can improve efficiency in the warehouse management segment as well as cost savings [2].

Kiran Pujari and the team of Department of Information Technology, Nasik, India, Italy under the title "Android Application by using NFC technology for Hospital Management System" was conducted. In this study NFC technology is used for built-in modules with identification tags that allow the system to identify, store and retrieve data for patients forming a back-end server. From research conducted with NFC Technology tags that are identified with smart-phone for hospital operations have the advantage to reduce the hospital's operational costs [4].

\section{SMART CITY}


Smart City has a multi-interpretation concept. What makes multi-interpretation in essence is the term or concept of "smart" defines smart as acting, thinking and acting intelligently in the work done. Further more he says smart is manifested by the sport through intense intuition, though the ratio through creativity and innovation leads to breakthroughs, and sports through impressive actions. South Korea, translating smart city as "knowledge" city, "digital" city, "cyber city" or "eco" city all at once. However, regardless of the interpretation given for the concept of smart city, the essence that should not be lost is the improvement or sustainable development of the city, still taking into account the functional, structural and aesthetic aspects, through the use of communication and information technology as its infrastructure base [11].

In this study the activities that will be integrated with smart city are Integrated Service Post. Community Based Health Effort (UKBM) implemented by, from and with the community, to empower and provide convenience to the community to obtain health services for mothers, infants and toddlers [1]. The Integrated Service Post activities consist of the main activities and development/ selection activities. Main activities, including:

- Health of both mother and child

- Family planning

- Immunization

- Nutrition

- Prevention and Control of Diarrhea.

This research focus on develop system for collecting infant and toddler data health, in weight and height periodically.

Functionally, the future city of dreams should be able to accommodate people (people) with their respective functions, whether as economic or business actors, social actors, government actors, who can work quietly, safely and comfortably supported by infrastructure roads and railways, bridges, ports, airports, banking and information technology. [11]

Structurally, the intended future city of dreams must be able to ensure institutional and institutional systems run smoothly, whether in economic or business, social, and government [11]. So smart city is a city designed with an eco-friendly approach, friendly people, friendly technology, friendly governance, leave no beauty, friendly morality, no harmful externalities.

\section{APPLICATION DESCRIPTION}

This system is contains of two applications, android based application and web based application. The android based application is the interface for volunteer in community health care doing data recording and reporting. This application utilizes technology Near Field Communication (NFC) which integrated with e-KTP so that will facilitate process of registration and registration of Integrated Service Post participant. Data from e-KTP will connected to server department of population and civil registration for the validating. If data already registered, e-KTP used to recall history data of patient, the feature of the application showed in Figure 3. The main function of web application are monitoring the community health care activity, and create some reporting data about infant and toddler data health, some feature of this application showed in Figure 4 and 5. This web used by public primary health care officer in local area in Depok City. The connecting between the system showed by Figure 2.

Figure 3 shows some interface from android application for community health care. Its contain data about the family and children health data. Figure 4 and 5 show some dashboard interface for office Public PHC. There are some daily reports and also simple analysis children health data.

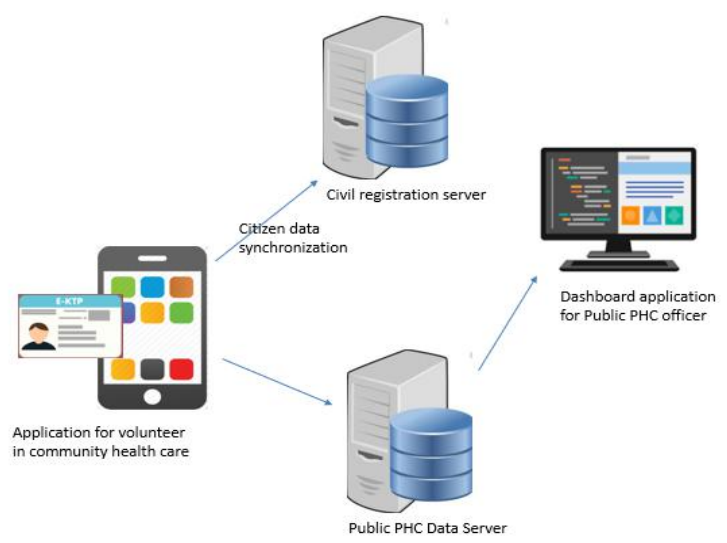

Figure 1 Business Process

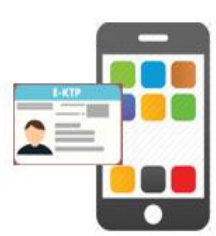

Application for volunteer in community health care

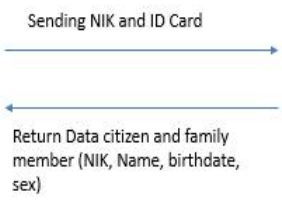

Figure 2 Communication Citizen Data

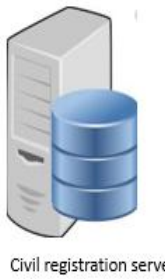

Civil registration server 


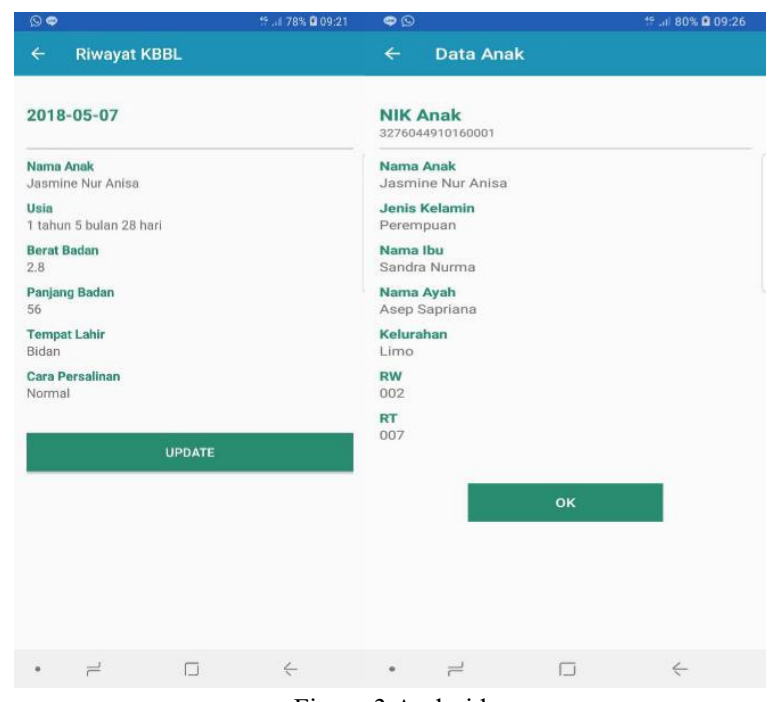

Figure 3 Android

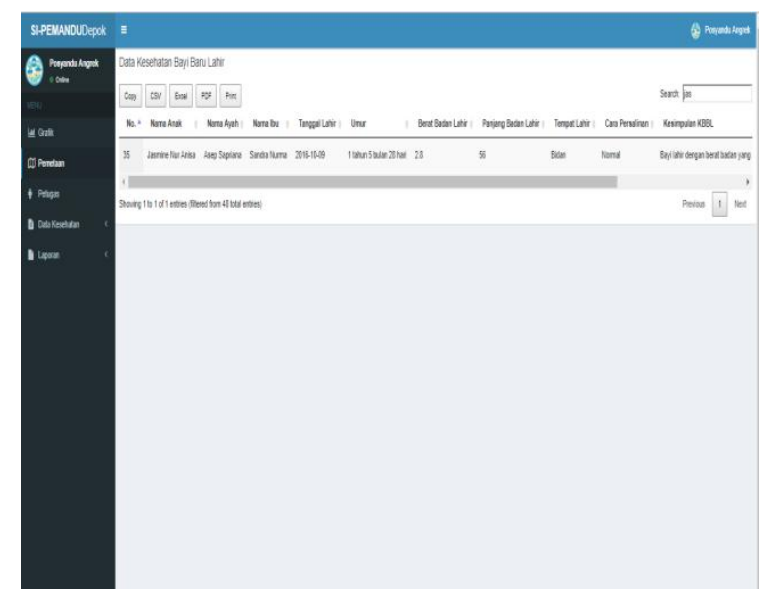

Figure $4 \mathrm{Kbbl}$

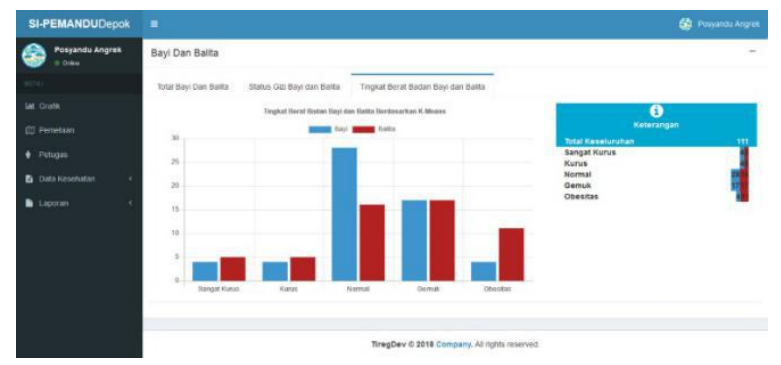

Figure 5 Chart

\section{TESTING}

The system was tested by using black-box testing. Black-box testing is a test that focuses on the workings or functional applications that are built. A testing process that focuses on how the work or functional applications are created and will be made against all the functional requirements that have been designed at the design stage of the application. This test was performed at 2 local community health care in Depok area. These are Anggrek Community Health Care and Melati Community Health Care in the Limo sub-district. The detail testing as follows:

\section{Anggrek Community Health Care}

This Community Health Care is located at Jalan Haji Midi RW 02, Limo sub-district Limo Kota Depok. This community is headed by Mrs. Nengsih and has 50 children of participants. Prior to this testing, the Community Health Care provided information to the Community Health Care participants to prepare e-KTP and family card to carry during the Community Health Care activity. Testing of the application is done on May 7, 2017 from 09.00 am until $11.00 \mathrm{pm}$ and using 2 pieces of android smart-phone. At the time of testing the officer as a user to do data recording child, Kartu Menuju Sehat (KMS) data, kbbl and immunization well and precisely. The total number of successful of orchid posyandu orchids through this application is only 17 children from the target of 34 children.

\section{Melati Community Health Care}

This Community Health Care is located at Jalan Pinang Lebong RW 015 Limo sub-district Limo Depok City. This community is headed by Mrs. Masanih and has 80 children of participants. Prior to this examination, the Community Health Care provided information to Community Health Care participants to prepare e-KTP and family card to carry during Community Health Care activities. Testing of application usage is done on May 11, 2017 from $09.00 \mathrm{AM}$ to $11.00 \mathrm{AM}$ and using 2 pieces of android smart-phone. At the time of testing the officer as the user to do data recording child, Kartu Menuju Sehat (KMS) data, kbbl and immunization well and precisely. The total number of successful children posyandu orchid input through this application is 33 children from target 41 children.

This data analysis is done based on result of testing which have been done at Anggrek Community Health Care and Melati Community Health Care in Limo sub-district of Limo City. In the Anggrek Community Health Care data analysis can be obtained from the time of application testing and the results of application testing, this data analysis relates to the data that succeeded in the recapture of only 17 participants with the number coming 30 participants from the target posyandu target of 50 participants. While at Anggrek Community Health Care analysis 
of this data relates to data that succeed in recap that only 33 participants with amount coming 41 participants from target of posyandu target as much 80 participants. Detailed analysis can be seen in the Table I.

TABLE I. DATA ANALYSIS

\begin{tabular}{|l|l|l|l|}
\hline No & \multicolumn{1}{|c|}{$\begin{array}{c}\text { Indicator Data } \\
\text { Analysis }\end{array}$} & $\begin{array}{c}\text { Anggrek } \\
\text { Community } \\
\text { Health } \\
\text { Care }\end{array}$ & $\begin{array}{c}\text { Melati } \\
\text { Community } \\
\text { Health } \\
\text { Care }\end{array}$ \\
\hline 1 & $\begin{array}{l}\text { Total Target } \\
\text { Audience }\end{array}$ & 50 & 80 \\
\hline 2 & $\begin{array}{l}\text { Total Attendance of } \\
\text { Participants }\end{array}$ & 34 & 41 \\
\hline 3 & $\begin{array}{l}\text { Total Attendee Data } \\
\text { Recognition }\end{array}$ & 17 & 33 \\
\hline 4 & $\begin{array}{l}\text { Participants E-KTP } \\
\text { Depok }\end{array}$ & 12 & 20 \\
\hline 5 & $\begin{array}{l}\text { Participants of E-KTP } \\
\text { Not Depok }\end{array}$ & 5 & 8 \\
\hline 6 & $\begin{array}{l}\text { Participants Do not } \\
\text { Have E-KTP }\end{array}$ & 7 & 13 \\
\hline 7 & Children Have NIK & 7 & 18 \\
\hline 8 & $\begin{array}{l}\text { Children Do not Have } \\
\text { NIK }\end{array}$ & 10 & \\
\hline
\end{tabular}

Here is the explanation based on the table of analysis of the indicator data above against the application testing conducted on Anggrek Community Health Care and Melati Community Health Care in the limo district of Depok city.

- By using this application then we can see and know quickly any Community Health Care which has the highest attendance level of participants and approve and even fit from the target target on each Community Health Care.

- By using this application the government will know the data of participants who have e-KTP Depok and not e-KTP Depok and who do not have e-KTP so that data will be very helpful for the government in making the right policy direction towards Community Health Care, especially Community Health Care participants who have e-KTP Depok as the right policy receiver in Depok city government area.

- By using this application the government, especially the civil service and civil registry can know the data of newborns or toddlers who do not have nik so that with the data disdukcapil party can take an effective policy on the problem.

\section{CONCLUSION}

The conclusions obtained based on the results of testing and data analysis of the application are this application can help volunteer in Community Health Care in doing data recording quickly and easily, it is based on the results of the questionnaire data that has been distributed to every volunteer. The NFC technology utilization feature in this application also allows for integration with e-KTP to facilitate volunteer in participant data collection as well as to monitor the health development of the participants quickly and accurately. The reporting process using this application is also very fast and can be seen directly by the Public Primary Health Care after the Community Health Care activities are completed.

This application is an application that is integrated with server of citizen data so that by using this application then the party from Civil Registration Department will know which child or newborn baby in Depok city who has not done the administration of residence while for the health office will know how many citizen in Depok city participated in Community Health Care activities. This application will also provide information to the Public Primary Health Care about the development of children's health in every area of the health center or Community Health Care. Application of this will be in line with the mission of Depok city government to build Smart City Depok city and this application can also be part of Smart City application Depok City.

\section{REFERENCES}

[1] Depkes, 2013. Buku Panduan Posyandu. [Online] Available at: http://www.depkes.go.id/. [9 Januari 2018].

[2] Liu, Fagui, et al. 2016.The Application of NFC Verification System in Warehouse Management System.(ICIMM2016) .School of Computer Science and Engineering, South China University of Technology, Guangzhou, China.

[3] Pressman, Roger S. and Maxim, Bruce R. 2014. Software Engineering A Practitioner's Approach. New York: McGraw Hill Education.

[4] Pujari, Kiran, et al.2014. NFC+ Android Application by using NFC technology for Hospital Management System. Department of Information Technology Nasik. International Journal of Research in Advent Technology, Vol.2, No.2, April 2014. E-ISSN: 2321-9637.

[5] Putra, Konradus M.K. 2013. Rancang Bangun Aplikasi Pembayaran Transportasi Bus Menggunakan Teknologi Near Field Communication pada Perangkat Mobile. Magister Teknik Informatika Universitas Atma Jaya Yogyakarta, Yogyakarta.

[6] Rosa AS dan M.Shalahuddin. 2015. Rekayasa Perangkat Lunak Terstruktur dan Berorientasi Objek. Bandung: INFORMATIKA. 
[7] Safaat H, Nazruddin, 2012, Pemrograman Aplikasi Mobile smart-phone dan Tablet PC Berbasis Android (edisi revisi). Informatika, Bandung.

[8] Saiful Haq, Agus Suharsono, Suji. 2014. Kualitas Pelayanan Publik Dalam Pembuatan e-KTP Pada Kecamatan Suboh Kabupaten Situbondo. Jurusan Ilmu Administrasi Negara UNEJ.

[9] Saparkhojayev, Nurbeck, et al.2014. Access Control and Management System Based on NFC- Technology by the Use of Smart Phones as Keys. Middle-East Journal of Scientific Research 21 (7): pp 1130-1135. ISSN 1990-9233.
[10] Savitri, Nadia dan Heru Nurwasito. 2018. Pengembangan Aplikasi Mobile untuk Pelayanan Administrasi Posyandu dengan menggunakan Google Maps Api Geolocation Tagging. Fakultas Ilmu Komputer, Universitas Brawijaya. Jurnal PTIK. e-ISSN: 2548-964X.

[11] Yahya, Arief. 2013. Great Spirit Grand Strategy: Corporate Philosophy, Leadership Architecture and Corporate Culture for Sustainable Growth.Gramedia, Jakarta.

[12] Yurindra, 2017. Software Engineering. Yogyakarta: CV. Budi Utama. 